\title{
ANGKA KEJADIAN PENDERITA LUKA BAKAR DI BAGIAN/SMF BEDAH RSUP PROF. DR. R. D. KANDOU MANADO PERIODE JUNI 2011 SAMPAI JUNI 2014
}

\author{
${ }^{1}$ Gabriela Kairupan \\ ${ }^{2}$ Alwin Monoarfa \\ ${ }^{2}$ M. Hatibie
}

\author{
${ }^{1}$ Kandidat Skripsi Fakultas Kedokteran Universitas Sam Ratulangi Manado \\ ${ }^{2}$ Bagian/SMF Ilmu Bedah Fakultas Kedokteran Universitas Sam Ratulangi Manado \\ Email: ghebiee@gmail.com
}

\begin{abstract}
Burns are injuries caused by touching the surface of the body with objects that generate heat or substances that are burned. Burns caused by the transfer of energy from a heat source to the body. Heat can be transferred through conduction or electromagnetic radiation. Globally, nearly 96,000 children under the age of 20 suffered injuries from burns in 2004. Most of the deaths occur in poorer regions of the world - Africa and Southeast Asia, and countries with low and middle income countries in the Eastern Mediterranean region. This was a descriptive retrospective study by using the medical record in the Department of Surgery, Prof. Dr. R. D. Kandou Hospital Manado at period June 2011 to June 2014. The incidence of burns occurred in the 0-10 age range were 44 cases (29.2\%), followed by the age range of $11-20$ years as many as 33 cases $(11.9 \%)$. The highest incidence was in men with a number of cases 114 (75.5\%). Burns were most common among those who had not worked as many as 68 cases (45.0\%). The most frequent cause of burns was electricity as many as 58 cases (38.4\%). Conclusion: Patients with burns from June 2011 to June 2014 were 151 cases, the highest incidence was at age $<10$ years and between 11-20 years, males, and those who had not worked. Burns were mostly caused by electricity, followed by hot water.
\end{abstract}

Keywords: burns, incidence

\begin{abstract}
Abstrak: Luka bakar adalah luka yang terjadi akibat sentuhan permukaan tubuh dengan bendabenda yang menghasilkan panas atau zat-zat yang bersifat membakar. Luka bakar disebabkan oleh pengalihan energi dari suatu sumber panas kepada tubuh. Panas dapat dipindahkan lewat hantaran atau radiasi elektromagnetik. Secara global, hampir 96.000 anak-anak dibawah usia 20 tahun mengalami cedera akibat luka bakar di tahun 2004. Kebanyakan kematian terjadi di daerah miskin di dunia - Afrika dan Asia Tenggara, dan negara-negara pendapatan rendah dan menengah di daerah Mediterania Timur. Penelitian ini menggunakan metode retrospektif deskriptif melalui penelitian data rekam medik di Bagian Bedah RSUP Prof. Dr. R.D. Kandou Manado periode Juni 2011 sampai Juni 2014. insiden terbanyak terjadi pada rentang umur 0-10 sebanyak 44 kasus atau sebesar 29,2 \%, diikuti oleh rentang umur 11-20 tahun sebanyak 33 kasus atau sebesar 11,9\%. Insiden terbanyak pada laki-laki dengan jumlah kasus 114 atau sebesar 75,5 \%, bahwa insiden luka bakar paling banyak terjadi pada mereka yang belum bekerja yaitu sebesar 68 kasus (45,0 \%), penyebab paling banyak adalah luka bakar listrik yaitu sebesar 58 kasus (38,4 \%), Berdasarkan hasil penelitian kesimpulannya, Hasil penelitian menunjukkan, penderita luka bakar sejak Juni 2011 sampai Juni 2014 sebanyak 151 kasus, terbanyak pada umur <10 tahun dan antara 11-20 tahun, laki-laki dan mereka yang belum bekerja. Luka bakar paling banyak disebabkan oleh listrik setelah itu dengan air panas.
\end{abstract}

Kata kunci: luka bakar, angka kejadian 

Luka bakar adalah luka yang terjadi akibat sentuhan permukaan tubuh dengan bendabenda yang menghasilkan panas (api secara langsung maupun tidak langsung, pajanan suhu tinggi dari matahari, listrik, maupun bahan kimia, air, dll) atau zat-zat yang bersifat membakar (asam kuat, basa kuat). ${ }^{1}$ Kulit adalah organ tubuh terluas yang menutupi otot dan mempunyai peranan dalam homeostasis. Kulit merupakan organ terberat dan terbesar dari tubuh. Seluruh kulit beratnya sekitar $16 \%$ berat tubuh, pada orang dewasa sekitar 2,7 - 3,6 kg dan luasnya sekitar 1,5-1,9 $\mathrm{m}^{2}$. Tebalnya kulit bervariasi mulai $0,5 \mathrm{~mm}$ sampai $6 \mathrm{~mm}$ tergantung dari letak, umur dan jenis kelamin. Kulit tipis terletak pada kelopak mata, penis, labium minus dan kulit bagian medial lengan atas. Sedangkan kulit tebal terdapat pada telapak tangan, telapak kaki, punggung, bahu dan bokong. Secara embriologis kulit berasal dari dua lapis yang berbeda, lapisan luar adalah epidermis yang merupakan lapisan epitel berasal dari ectoderm sedangkan lapisan dalam yang berasal dari mesoderm adalah dermis atau korium yang merupakan suatu lapisan jaringan ikat. ${ }^{1-3}$

Luka bakar disebabkan oleh pengalihan energi dari suatu sumber panas kepada tubuh. Panas dapat dipindahkan lewat hantaran atau radiasi elektromagnetik. Luka bakar dapat dikelompokkan menjadi luka bakar termal, radiasi atau kimia. Destruksi jaringan terjadi akibat koagulasi, denaturasi protein atau ionisasi sel. Kulit dan mukosa saluran nafas atas merupakan lokasi destruksi jaringan. Jaringan yang dalam, termasuk organ visera, dapat mengalami kerusakan karena luka bakar elektrik atau kontak yang lama dengan agent penyebab (burning agent). Nekrosis dan kegagalan organ dapat terjadi. Dalamnya luka bakar tergantung pada suhu agen penyebab luka bakar dan lamanya kontak dengan agen tersebut. ${ }^{1,4}$

Secara global, hampir 96.000 anakanak dibawah usia 20 tahun mengalami cedera akibat luka bakar di tahun 2004. Angka kematian di negara dengan pendapatan rendah dan menengah adalah sebelas kali lebih tinggi daripada negara maju yaitu sebesar 4.3 per 100.000 berbanding 0,4 per 100.000 di negara maju. Kebanyakan kematian terjadi di daerah miskin di dunia - Afrika dan Asia Tenggara, dan negara-negara pendapatan rendah dan menengah di daerah Mediterania Timur. ${ }^{5}$

Selain cedera luka bakar yang disebabkan oleh kecelakaan rumah tangga, peningkatan angka kejadian luka bakar tidak lepas dari maraknya penggunaan listrik yang menyebabkan banyaknya kejadian kebakaran di Sulawesi Utara khususnya. Menurut data Perusahaan Listrik Negara Persero Sulutenggo, tingkat pencurian listrik di Sulawesi Utara masih sangat tinggi. Di Kota Bitung menurut Manager PLN Cabang Kota Bitung, tahun 2010 terdapat 5000 penggunaan listrik ilegal. ${ }^{6}$ Di Kota Manado, kasus musibah kebakaran hingga bulan Maret 2014 ini dibandingkan tahun lalu ada kenaikan yang cukup signifikan. Sesuai informasi yang diperoleh di Dinas Pemadam Kebakaran (Damkar) Manado, untuk bulan Maret pertanggal 24, telah terjadi 10 kasus. Sementara untuk bulan Januari hingga Pebruari 2014 lalu, telah mencapai 24 kasus. Dari data keseluruhan kasus pemicunya didominasi oleh arus pendek listrik. $^{7}$

\section{METODE PENELITIAN}

Penelitian ini menggunakan metode retrospektif deskriptif melalui penelitian data rekam medik untuk mengetahui angka kejadian penderita luka bakar di Bagian/SMF Bedah RSUP Prof. Dr. R. D. Kandou Manado periode Juni 2011 sampai Juni 2014. Hasil penelitian diuraikan dalam bentuk tabulasi penelitian presentase masing-masing.

\section{HASIL PENELITIAN DAN BAHASAN}

Data hasil penelitian retrospektif deskriptif penderita luka bakar di Bagian Bedah BLU RSUP Prof. Dr. R.D. Kandou Manado periode Juni 2011 sampai Juni 2014, hanya diperoleh data 151 kasus. Buruknya sistem perekaman medik 
mungkin mempengarui jumlah ini. Jumlah tersebut diperoleh dari periode 2011 sebanyak 22 kasus, 2012 sebanyak 41 kasus, 2013 sebanyak 66 kasus dan 2014 sebanyak 22 kasus. Untuk memudahkan penilaian, data-data yang ada dikelompokkan menurut variabel-variabel.

Tabel 1. Distribusi penderita luka bakar berdasarkan umur

\begin{tabular}{ccc}
\hline Umur (tahun) & $\mathrm{n}$ & $\%$ \\
\hline $0-10$ & 44 & 29,2 \\
$11-20$ & 30 & 19,9 \\
$21-30$ & 21 & 13,9 \\
$31-40$ & 21 & 13,9 \\
$41-50$ & 14 & 9,3 \\
$51-60$ & 10 & 6,6 \\
$61-70$ & 7 & 4,6 \\
$>71$ & 4 & 2,6 \\
\hline Total & 151 & 100 \\
\hline
\end{tabular}

Tabel 2. Distribusi penderita luka bakar berdasarkan jenis kelamin

\begin{tabular}{lcc}
\hline Jenis kelamin & $\mathrm{n}$ & $\%$ \\
\hline Laki-laki & 114 & 75,5 \\
Perempuan & 37 & 24,5 \\
\hline Total & 151 & 100 \\
\hline
\end{tabular}

Tabel 3. Distribusi penderita luka bakar berdasarkan pekerjaan

\begin{tabular}{lcc}
\hline Pekerjaan & $\mathrm{n}$ & $\%$ \\
\hline Buruh bangunan & 12 & 8,0 \\
Wiraswasta & 20 & 14,3 \\
Nelayan & 4 & 2,6 \\
Petani & 11 & 7,3 \\
Pegawai swasta & 13 & 9,6 \\
Pegawai negeri & 10 & 6,6 \\
IRT & 13 & 9.6 \\
Tidak bekerja & 68 & 45,0 \\
\hline Total & 151 & 100 \\
\hline
\end{tabular}

Tabel 4. Distribusi penderita luka bakar berdasarkan diagnosis

\begin{tabular}{lcc}
\hline Diagnosis & $\mathrm{n}$ & $\%$ \\
\hline Combustio ec listrik & 58 & 38,4 \\
Combustio ec air panas & 41 & 27,2 \\
Combustio ec api & 38 & 25,2 \\
Combustio ec minyak panas & 6 & 4,0 \\
Combustio lain-lain & 8 & 5,2 \\
\hline Total & 151 & 100 \\
\hline
\end{tabular}

Penderita luka bakar di Manado periode Juni 2011 sampai Juni 2014, diperoleh 151 kasus. Data ini mungkin lebih sedikit, mengingat di Kota Manado saja setiap bulannya hampir 10-15 kasus kebakaran yang terjadi dan terus meningkat hingga 2014.

Usia anak-anak rentan dengan bahaya kebakaran, baik listrik maupun kecelakaan di rumah seperti tersiram air panas, knalpot kendaraan, ledakan gas dll. Pada penelitian ini insiden terbanyak terjadi pada usia $<10$ tahun disusul oleh usia 11-20 tahun.

Insiden luka bakar paling banyak terjadi pada laki-laki di bandingkan oleh perempuan. Tingginya insiden pada lakilaki berhubungan erat dengan pekerjaan yang beresiko insiden kebakaran atau tersengat aliran listrik. ${ }^{8,9}$

Usia yang rentan mengalami luka bakar adalah anak-anak yang aktif dibawah usia 10 tahun. Keamanan rumah sangat penting untuk menghindari instalasi listrik yang tidak aman, penggunaan kabel yang terlalu banyak, dapur yang tidak aman sehingga usia ini lebih rentan.

Luka bakar akibat listrik masih menempati urutan teratas cedera yang dialami oleh penderita. Pencurian listrik yang marak terjadi, sambungan langsung dari kabel PLN tanpa pembatas, sambungan ilegal, beban listrik yang tinggi pada satu sambungan, kabel terbuka akibat gigitan tikus memicu terjadinya sengatan listrik. ${ }^{9}$ Sangat penting dilakukan himbauan kepada seluruh masyarakat agar lebih memperhatikan keadaan sambungan listrik di rumah masing-masing, menghubungi pihak PLN bila terdapat kabel atau sambungan yang mencurigakan, untuk menghindari sengatan listrik, sambungan arus pendek, sehingga kebakaran dapat dihindari. $^{10}$

\section{SIMPULAN}

Dari hasil penelitian dapat disimpulkam bahwa penderita luka bakar sejak Juni 2011 sampai Juni 2014 sebanyak 151 kasus. Insiden terbanyak terjadi pada umur <10 tahun dan 11-20 tahun, lebih banyak terjadi pada laki-laki dibandingkan 
perempuan. Insiden cedera listrik ditempati oleh mereka yang belum bekerja, termasuk pada kelompok ini ialah anak-anak dan remaja.

Pasien luka bakar paling banyak disebabkan oleh listrik setelah itu dengan air panas.

\section{SARAN}

1. Perlu dilakukan penelitian yang lebih lengkap, lebih mendalam dan komprehensif tentang insiden luka bakar di RSUP Prof. Dr. R. D. Kandou Manado.

2. Insiden luka bakar meningkat dari tahun ketahun, data yang ditemukan mungkin sedikit. Pencacatan medis yang belum ada perbaikan di RSUP Prof R.D. Kandow sehingga banyak data pasien yang hilang atau tidak tercatat di rekam medis, oleh karena itu perlu diperbaiki, demi penelitian berikutnya.

\section{DAFTAR PUSTAKA}

1. de Jong W. Luka, luka bakar. In Buku Ajar Ilmu Bedah (2nd ed). Jakarta: EGC, 2005; p. 66-88.

2. McGrath JA, Eady RJ, Pope FM. Anatomy and organization of human skin. New York: Oxford University press, 2009.

3. Brunicardi FC, Andersen DK, Billiar TR, Dunn DL, Hunter JG, Pollock RE. Burns. In Schwartz's, Principles of surgery (8th ed.). New York:
McGraw-Hill's, 2005.

4. Gallagher JJ, Wolf SE, Herdon DN. Burns. In Townsend CM. Sabiston, Textbook of Surgery (18th ed.). Houston: Saunder Elsevier; 2007.

5. UNICEFF. Children and burns. WHO; 2005.

6. Manado B. [Online]. [cited 2014 September 25. Available from: HYPERLINK http://beritamanado.com/2011/04/16/ pencurian-listrik-di-bitung-makinmarak/.

7. Pemerintah Kota Manado. [Online].; 2014 [cited 2014 September 25. Available from: HYPERLINK http://www.manadokota.go.id/berita1304-antisipasi-kebakaran-wawaliimbau-warga-waspadai-instalasilistrik-.html .

8. Tim Bantuan Medis. [Online].; 2011 [cited 2014 Sep 26. Available from: http://www.tbm110.org/artikelmedis/manajemen-luka-bakar .

9. Rab H. Agenda gawat darurat (Critical Care): pengetasan kritis pada intergumenter- luka bakar. Bandung: PT. Alumni, 2005.

10. Pemerintah Kota Manad. Manadokota.go.id. [Online].; 2014 [cited 2015 Januari 20. Available from:

http://www.manadokota.go.id/berita1304-antisipasi-kebakaran-wawaliimbau-warga-waspadai-instalasilistrik-.html. 